\title{
Contribution of different HFE genotypes to iron overload disease: a pooled analysis
}

Wylie Burke, $M D, P h D^{1,2}$, Giuseppina Imperatore, $M D, P h D^{2}$, Sharon M. McDonnell, $M D, M P H^{3}$, Roy C. Baron, $M D$, $M P H^{3}$, and Muin J. Khoury, $M D, P h D^{4}$

\begin{abstract}
Purpose: To determine the contribution of the $\mathrm{C} 282 \mathrm{Y}$ and $\mathrm{H} 63 \mathrm{D}$ mutations in the HFE gene to clinical expression of hereditary hemochromatosis. Methods: Pooled analysis of 14 case-control studies reporting HFE genotype data, to evaluate the association of different HFE genotypes with iron overload. In addition, we used data from the pooled analysis and published data to estimate the penetrance of the $\mathrm{C} 282 \mathrm{Y} / \mathrm{C} 282 \mathrm{Y}$ genotype. Results: Homozygosity for the $\mathrm{C} 282 \mathrm{Y}$ mutation carried the largest risk for iron overload (OR $=4383,95 \% \mathrm{Cl} 1374$ to $>10,000)$ and accounted for the majority of hemochromatosis cases (attributable fraction $(A F)=0.73$ ). Risks for other genotypes were much smaller: $\mathrm{OR}=32$ for genotype $\mathrm{C} 282 \mathrm{Y} / \mathrm{H} 63 \mathrm{D}(95 \% \mathrm{Cl} 18.5$ to $55.4, \mathrm{AF}=0.06)$; OR $=5.7$ for $\mathrm{H} 63 \mathrm{D} / \mathrm{H} 63 \mathrm{D}(95 \% \mathrm{Cl} 3.2$ to $10.1, \mathrm{AF}=0.01)$; $\mathrm{OR}=4.1$ for $\mathrm{C} 282 \mathrm{Y}$ heterozygosity $(95 \% \mathrm{Cl} 2.9$ to 5.8 , with heterogeneity in study results, making this association uncertain); and $\mathrm{OR}=1.6$ for $\mathrm{H} 63 \mathrm{D}$ heterozygosity $(95 \% \mathrm{Cl}$ 1 to $2.6, \mathrm{AF}=0.03$ ). Estimates of penetrance for the $\mathrm{C} 282 \mathrm{Y} / \mathrm{C} 282 \mathrm{Y}$ genotype were highly sensitive to estimates of the prevalence of iron overload disease. At a prevalence of 2.5 per 1000 or less, penetrance of the $\mathrm{C} 282 \mathrm{Y} / \mathrm{C} 282 \mathrm{Y}$ genotype is unlikely to exceed $50 \%$. Penetrance of other HFE genotypes is much lower. Conclusions: $\mathrm{C} 282 \mathrm{Y}$ homozygosity confers the highest risk for iron overload but the H63D mutation is also associated with increased risk. Our data indicate a gradient of risk associated with different HFE genotypes and thus suggest the presence of other modifiers, either genetic or environmental, that contribute to the clinical expression of hemochromatosis. Genetics in Medicine, 2000:2(5):271-277.
\end{abstract}

Key Words: hemochromatosis, iron overload, HFE gene, C282Y mutation, H630 mutation, penetrance

Hereditary hemochromatosis is a common genetic disorder for which there is a simple and effective intervention. ${ }^{1.2}$ The complications of hemochromatosis are caused by iron overload - that is, the accumulation of excess iron in body tissues. These complications include cirrhosis, primary liver cancer, diabetes, and cardiomyopathy; they can be prevented by treatment with periodic phlebotomy. ${ }^{1,2}$ The gene for hemochromatosis, designated HFE, has been sequenced, and two HFE mutations, C282Y and H63D, have been identified..$^{3,4}$ With the discovery of these mutations, genetic testing has been proposed as a means to identify people with hemochromatosis before symptoms occur, so that preventive treatment can be initiated. ${ }^{5,6}$ To use genetic testing for either screening or diagnosis, however, the association between different HFE geno-

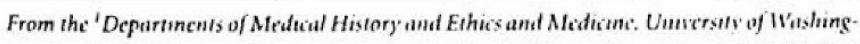
ton, Seattle, Washington: "National Center for Chronic Discitse Prevention and Health Pro. motion, Ceuters for Diseuse Control and Prevention: 'Epidemiology Program Office, Centers for Diseasc Control nud Prevention; and 'Uffice of Genetics and Discase Pretrmion. Couters for Discase Cuntrol and Prestrmion. Atlanta, Georgia.

IVylic Burke. MD, PhD, Depurtmient of Mcitial Histor and Ethics, Rox 357120). Limiversity

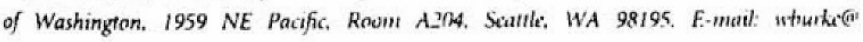
u.washiugton.cdu.

Recived: March 30, 2000.

Accepied: May 26, 2000 types and the clinical expression of hemochromatosis must be established.

In published clinical studies, the majority of hemochromatosis cases have been homozygous for the $\mathrm{C} 282 \mathrm{Y}$ mutation, but the percentage in different populations has varied from 52 to $100 \% .^{3.7-21}$ Among the remaining cases, several other HFE genotypes have been found, including compound heterozygotes (C282Y/H63D, $0-7 \%$ of cases), H63D homozygotes $(0-4 \%$ of cases), and heterozygotes for each of the two known mutations $(0-15 \%$ of cases). There were no identifiable HFE mutations in 0 to $21 \%$ of cases.

The low frequency of compound heterozygotes (C282Y) H63D) and H63D homozygotes among hemochromatosis cases is unexpected, because the $\mathrm{H} 63 \mathrm{D}$ mutation is more common than the $\mathrm{C} 282 \mathrm{Y}$ mutations in the general population. Among control subjects, H63D heterozygotes are consistently found two to three times more frequently than $\mathrm{C} 282 \mathrm{Y}$ heterozygotes. ${ }^{10,12,15,18}$ As a result, genotypes containing the H63D mutation - including both the $\mathrm{C} 282 \mathrm{Y} / \mathrm{H} 63 \mathrm{D}$ and the H63D/H63D genotypes - occur more frequently in the population than the $\mathrm{C} 282 \mathrm{Y} / \mathrm{C} 282 \mathrm{Y}$ genotype. The low proportion of genotypes containing the H63D mutation among hemochromatosis cases thus suggests either a weak association with clinical expression of disease or lack of an association. The 
association between the $\mathrm{C} 282 \mathrm{Y}$ or $\mathrm{H} 63 \mathrm{D}$ heterozygosity and clinical disease is also uncertain.

These observations make it difficult to determine what constitutes a positive result when HFE mutation testing is done. To address this question, we have performed a pooled analysis, using data from 14 studies that evaluated HFE genotypes in hemochromatosis case and control populations. The purpose of the pooled analysis was to determine whether genotypes other than $\mathrm{C} 282 \mathrm{Y} / \mathrm{C} 282 \mathrm{Y}$ had a causal association with hemochromatosis or could be explained by chance. Data from the pooled analysis were also used, in combination with prevalence data, to estimate the penetrance of HFE genotypes.

\section{METHODS}

\section{Selection of studies for pooled analysis}

The studies used in the pooled analysis were identified by a computerized search of the PubMed database (National Library of Medicine) done in September 1999, using the search terms "hemochromatosis and HFE," and from the references cited in the articles located through the search. Studies were included if they met the following criteria: (1) the frequency of the HFE mutations $\mathrm{C} 282 \mathrm{Y}$ and $\mathrm{H} 63 \mathrm{D}$ was reported for persons with a diagnosis of hemochromatosis and for control subjects; (2) the case definition for hemochromatosis included a measure of iron overload (elevated serum ferritin, elevated hepatic iron index or other measure of excess iron based on liver biopsy, or evidence of iron overload by quantitative phlebotomy), with cases otherwise unselected; and (3) the population studied was Caucasian. When more than one study reported data from the same study population, we used the most recent published report. We identified 14 studies meeting these criteria. $3,8-13,15-21$ These studies reported on study populations from Europe, New Zealand, and North America. In most studies, case and control subjects were recruited from different sources (Table 1). Most studies derived cases from clinical referral centers; however, three studies ${ }^{10,12,15}$ derived cases from a screened population. Case definitions for each study are summarized in Table 1.

\section{Statistical analysis}

We computed the odds ratio (OR) for hemochromatosis for each of five HFE genotypes that included a known mutation (C282Y/C282Y, C282Y/H63D, H63D/H63D, C282Y/t, $\mathrm{H} 63 \mathrm{D} /+)$, using individuals with neither mutation as the referent group. ORs were computed both for the individual studies and for the pooled analysis of 14 studies, using the MantelHaenszel procedure. ${ }^{22}$ To rule out marked variation that would invalidate a pooled analysis, we assessed the heterogeneity of ORs across studies using the Breslow-Day test. Using the pooled OR, we estimated a crude population attributable fraction (AF, defined as the proportion of cases with disease attributable to a particular genotype) for the different geno- types in each study using Miettinen's formula as shown below ${ }^{22}$; this estimate was not weighted by individual study size.

$$
\begin{aligned}
& \mathrm{AF}_{\mathrm{HFE} \text { genotype }} \\
& \qquad \begin{array}{l}
=\left[( \text { Fraction of cases with genotype } ) \left(\mathrm{OR}_{\mathrm{HFE} \text { genorype }}\right.\right. \\
-1)] /\left[\mathrm{OR}_{\mathrm{HFE} \mathrm{genotype}}\right]
\end{array}
\end{aligned}
$$

\section{Estimates of penetrance}

We defined penetrance as the number of persons with a given genotype who manifest iron overload disease during their lifetime, divided by the total number of people with the genotype. Penetrance $(\mathrm{P})$ was estimated using the following formula, where $\operatorname{Pr}_{\mathrm{IOD}}=$ the prevalence of iron overload disease due to hemochromatosis, $\mathrm{C}_{\mathrm{CY} / \mathrm{CY}}=$ the proportion of cases of iron overload disease due to the C282Y/C282Y genotype, and $\mathrm{Pr}_{\mathrm{CY} / \mathrm{CY}}=$ the prevalence of the $\mathrm{C} 282 \mathrm{Y}$ genotype:

Penetrance of $\mathrm{C} 282 \mathrm{Y} / \mathrm{C} 282 \mathrm{Y}=\left[\left(\mathrm{Pr}_{\mathrm{IOD}}\right)\left(\mathrm{C}_{\mathrm{CY} / \mathrm{CY}}\right)\right] / \mathrm{Pr}_{\mathrm{CY} / \mathrm{CY}}$

Values for the calculation were estimated as follows.

\section{Prevalence of iron overload disease}

Published reports were used to estimate the prevalence of iron overload disease due to hemochromatosis. ${ }^{15,23-26}$ These reports indicate that there is considerable uncertainty about the prevalence of iron overload disease, due to differences in case definition. Screening studies have estimated prevalence based on the presence of biochemical measures of iron overload (such as persistently elevated transferrin saturation in combination with an elevated serum ferritin or an abnormal liver biopsy) in people who may be asymptomatic. In such studies, the prevalence of iron overload disease is estimated to range from 2 to 5 per $1000 .{ }^{15,23-26}$ However, symptomatic expression of iron overload disease may occur in as few as $50 \%$ of persons with biochemical evidence iron overload, 23,27 and serious complications of iron overload may occur in even fewer. ${ }^{28}$ For this reason, we have calculated penetrance of the $\mathrm{C} 282 \mathrm{Y} / \mathrm{C} 282 \mathrm{Y}$ genotype for three base cases varying in prevalence of iron overload disease from 1 per 1000 to 5 per 1000 .

\section{Proportion of cases due to C282Y/C282Y}

Using combined data from the 14 studies in the pooled analysis, we assumed that $75 \%$ of cases carried the $\mathrm{C} 282 \mathrm{Y} / \mathrm{C} 282 \mathrm{Y}$ genotype in the base case. For sensitivity analyses, the proportion was varied from $55 \%$ to $95 \%$.

\section{Prevalence of the C282Y/C282Y genotype}

The prevalence of the $\mathrm{C} 282 \mathrm{Y} / \mathrm{C} 282 \mathrm{Y}$ genotype used for the base case was estimated at $0.5 \%$, from combined data of the four studies in the pooled analysis that used unselected screened populations to measure the prevalence of different HFE genotypes ${ }^{10,12,15,18}$; this value was consistent with other published data of HFE genotype prevalence. ${ }^{29}$ For sensitivity analyses, the prevalence was varied from $0.4 \%$ to $0.6 \%$. 
Table 1

Characteristics of study populations

\begin{tabular}{|c|c|}
\hline Study & Control subjects \\
\hline Beutler et al., 1996 (US) & Individuals of European origin $(N=193)$ \\
\hline $\begin{array}{l}\text { Borot et al., } 1997 \\
\text { (France) }\end{array}$ & $\begin{array}{l}\text { Healthy unrelated individuals of similar } \\
\text { ethnic background to cases }(N=95)\end{array}$ \\
\hline $\begin{array}{l}\text { Burt et al., } 1998 \text { (New } \\
\text { Zealand) }\end{array}$ & $\begin{array}{l}\text { Random sample of adult on Christchurch } \\
\text { electoral rolls }(N=1056)\end{array}$ \\
\hline $\begin{array}{l}\text { Cardoso et al., } 1998 \\
\text { (Sweden) }\end{array}$ & $\begin{array}{l}\text { Random healthy Swedish subjects, sampled } \\
\text { anonymously from DNA databank ( } N= \\
117 \text { ) }\end{array}$ \\
\hline $\begin{array}{l}\text { Distante et al., } 1999 \\
\text { (Norway) }\end{array}$ & $\begin{array}{l}\text { Hospital employees living in a Oslo } \\
\text { recruited to screening study }(N=482)\end{array}$ \\
\hline Feder et al., 1996 (US) & $\begin{array}{l}\text { Caucasian subjects from the grandparental } \\
\text { generation of the CEPH collection }(N= \\
\text { 155) }\end{array}$ \\
\hline
\end{tabular}
155)

Gottschalk et al., $1998 \quad$ Healthy blood donors $(N=153)$
(Germany)

McDonnell et al., 1999 (US)

Health maintenance organization employees recruited to screening study $(N=1648)$

Moirand et al., 1999

(France)

Mura et al., 1999

(France)

Randomly selected unrelated individuals $(N=410)$

Blood donors, hospital staff, and members of the general population $(N=139)$

Murphy et al., 1998 (Ireland)

Volunteers from a Bone Marrow Registry $(N=404)$

Piperno et al., 1998 (Italy)

Source not specified $(N=139)$

Sanchez et al., 1998

(Spain)

UK Haemochromatosis Consortium, 1997 (UK)
Blood donors $(N=420)$ and controls from paternity testing studies $(N=92)$

Healthy blood donors from Wales $(N=$ 101)
Probands of European origin, diagnosed by serum iron measures, liver biopsy, or response to phlebotomy $(N=147)$

Probands diagnosed by serum iron and ferritin levels, liver biopsy, and response to phlebotomy $(N=94)$

Individuals from random sample meeting criteria for hemochromatosis: persistently elevated TS $(>55 \%)$ and serum ferritin (females $>160 \mathrm{mg} / \mathrm{dL}$, males $>300 \mathrm{mg} / \mathrm{dL})(N=8)$

Unrelated probands with elevated TS (males $>60 \%$, females $>50 \%$ ) and elevated serum ferritin $(>300 \mathrm{mg} \mathrm{dL}$ ) or liver biopsy with increased iron staining $(N=87)$

Individuals from random sample meeting criteria for hemochromatosis: persistently elevated TS ( $\geq 50 \%)$ and serum ferritin $(\geq 200 \mathrm{mg} / \mathrm{dL})(N=23)$

Probands meeting two or more of the following criteria: hepatic iron concentration $>4500 \mu \mathrm{g} / \mathrm{g}$; hepatic iron index $>2$; grade $3+$ or $4+$ stainable iron in liver; $>4 \mathrm{~g}$ total iron removed by phlebotomy $(N$ $=178$ )

Probands meeting one or more of the following criteria: hepatic iron concentration $>33 \mu$ mole/g; hepatic iron index $>2$; or elevated mobilizable iron by quantitative phlebotomy $(N=57)$

Individuals from screened group meeting criteria for hemochromatosis: persistently elevated TS (males $\geq 60 \%$, females $\geq 50 \%$ ), serum ferritin $\geq 95^{\text {th }}$ percentile, and mobilizable iron $\geq 95$ th percentile $(N=5)$

Unrelated probands with histologic total iron score $>3$, liver iron $>36$ $\mu \mathrm{mol} / \mathrm{g}$; or hepatic iron index $>2$; or excess iron (males $>5 \mathrm{~g}$, females $>3 \mathrm{~g})$ removed by phlebotomy $(N=531)$

Unrelated probands meeting 2 or more of the following: (1) elevated TS (males $>60 \%$, females $>50 \%$ ); (2) elevated serum ferritin (males $>400 \mu \mathrm{g} / \mathrm{L}$, females $>300 \mu \mathrm{g} / \mathrm{L}$ ); (3) serum iron $>20 \mu \mathrm{mol} /$ $\mathrm{L}(\mathrm{N}=711)$

Patients diagnosed by clinical assessment and liver biopsy $(N=30)$

Unrelated probands meeting the following criteria: (1) repeated TS $>50$ and elevated serum ferritin; (2) hepatic iron staining of $3+$ or $4+$; (3) determined by hepatic iron index $\geq 2$ or excess iron removed by phlebotomy (males $>5 \mathrm{~g}$, females $>3 \mathrm{~g}$ ); (4) no iron loading anemia or history of blood transfusions $(N=188)$

Unrelated probands with TS $>55 \%$, elevated serum ferritin, other causes of iron overload excluded, and hemochormatosis confirmed by either hepatic iron staining of $3+$ or $4+$ or removal of $>5 \mathrm{~g}$ iron by phlebotomy $(N=31)$

Probands receiving care at four UK medical centers, diagnosed by hepatic index $>1.9$ or by $>5 \mathrm{~g}$ total iron removed by phlebotomy
$(N=115)$ 


\section{Penetrance of $\mathrm{C} 282 \mathrm{Y} / \mathrm{H} 63 \mathrm{D}$ and $\mathrm{H63D} / \mathrm{H} 63 \mathrm{D}$}

The same formula and the same range for prevalence of iron overload disease were used in calculations of the penetrance of the $\mathrm{C} 282 \mathrm{Y} / \mathrm{H} 63 \mathrm{D}$ and $\mathrm{H} 63 \mathrm{D} / \mathrm{H} 63 \mathrm{D}$ genotypes. Combined data from the 14 studies in the pooled analysis were used for the estimates of the proportion of cases carrying each of these genotypes (6\% for $\mathrm{C} 282 \mathrm{Y} / \mathrm{H} 63 \mathrm{D}$ and $1 \%$ for $\mathrm{H} 63 \mathrm{D} / \mathrm{H} 63 \mathrm{D})$. The prevalence rates of the $\mathrm{C} 282 \mathrm{Y} / \mathrm{H} 63 \mathrm{D}$ genotype $(2.2 \%)$ and the H63D/H63D genotype (2.5\%) were estimated by combining data from the four studies in the pooled analysis that measured the prevalence of different HFE genotypes in unselected screened populations. ${ }^{10,12,15,18}$ These values were consistent with other published data of HFE genotype prevalence. ${ }^{29}$

\section{RESULTS}

Pooled ORs for the different HFE genotypes are shown in Table 2. Homozygosity for the $\mathrm{C} 282 \mathrm{Y}$ mutation conferred the highest risk for iron overload $(\mathrm{OR}=4383,95 \% \mathrm{CI} 1374$ to $>10,000)$ and accounted for the majority of hemochromatosis cases in all studies (Table 2 ). The pooled AF for this genotype was 0.73 .

Other HFE genotypes were also associated with iron overload (Table 2). The OR for compound heterozygosity was 32 ( $95 \%$ CI 18.5 to 55.4 ), and the pooled AF was 0.06. Homozygosity for the $\mathrm{H} 63 \mathrm{D}$ mutation carried a smaller risk for iron overload (OR $=5.7,95 \%$ CI 3.2 to 10.1 ), with a pooled AF of 0.01 . The OR for C282Y heterozygosity was 4.1 ( $95 \%$ CI 2.9 to 5.8 ), with a pooled AF of 0.03 ; however, heterogeneity in the OR associated with this genotype was observed across studies $(P=0.02)$. H63D heterozygosity was also associated with an increased risk of iron overload; the pooled OR was $1.9(95 \% \mathrm{CI}$ 1.5 to 2.5 ), with a pooled AF of 0.03 .

Two of the studies in the pooled analysis ${ }^{13,21}$ used blood donors as control subjects. Because blood donation could mask affected status, these studies could have biased the results through misassignment of controls. Similarly, a study done in an Italian population ${ }^{19}$ could have biased results because of the lower prevalence of the $\mathrm{C} 282 \mathrm{Y}$ mutation in this population. ${ }^{19}$ Therefore, we repeated the pooled analysis after omitting these three studies. The results were equivalent to the pooled analysis of all 14 studies (ORs of 4389 for C282Y/C282Y, 30.9 for C292Y/H63D, 5.7 for H63D/H63D, 3.7 for C282Y/+ and 1.9 for $\mathrm{H} 63 \mathrm{D} /+$, with confidence intervals similar to those shown in Table 2).

Estimates for the penetrance of the $\mathrm{C} 282 \mathrm{Y} / \mathrm{C} 282 \mathrm{Y}$ genotype are shown in Figure $l$ and in Table 3. Figure 1 shows changes in estimated penetrance with differences in the prevalence of iron overload and the proportion of cases carrying the C282Y/ $\mathrm{C} 282 \mathrm{Y}$ genotype. These calculations assume a genotype prevalence of 5 per 1000 . Under these conditions, penetrance approaches $100 \%$ only when two conditions are present: (1) the prevalence of iron overload disease is 5 per 1000, and (2) the proportion of cases carrying the $\mathrm{C} 282 \mathrm{Y} / \mathrm{C} 282 \mathrm{Y}$ genotype also approaches $100 \%$. As the proportion of cases with the C282Y/ C282Y genotype decreases, so does penetrance. For lower rates of iron overload disease, penetrance is always below $50 \%$ and falls between $10 \%$ and $20 \%$ when iron overload is estimated at 1 in 1000 . Table 3 shows the effect of differences in the prevalence of the genotype: as the prevalence of $\mathrm{C} 282 \mathrm{Y} / \mathrm{C} 282 \mathrm{Y}$ increases, penetrance decreases.

We also estimated the penetrance of the $\mathrm{C} 282 \mathrm{Y} / \mathrm{H} 63 \mathrm{D}$ and H63D/H63D genotypes (Table 4). Estimates are shown for prevalence of symptomatic iron overload disease ranging from 1 per 1000 to 5 per 1000 . The penetrance for these genotypes was very low: penetrance of the $\mathrm{C} 282 \mathrm{Y} / \mathrm{H} 63 \mathrm{D}$ genotype ranged from $0.3 \%$ to $1.4 \%$, and penetrance of the $\mathrm{H} 63 \mathrm{D} / \mathrm{H} 63 \mathrm{D}$ genotype ranged from $0.04 \%$ to $0.2 \%$.

\section{DISCUSSION}

Data from the pooled analysis confirm that the C282Y/ C282Y genotype accounts for the majority of cases of iron overload due to hemochromatosis. However, in our analysis about $25 \%$ of cases had other HFE genotypes, including $14 \%$ with a normal HFE genotype. The pooled ORs indicate that both $\mathrm{C} 282 \mathrm{Y}$ and $\mathrm{H} 63 \mathrm{D}$ contribute to the clinical expression of hemochromatosis, although the penetrance of the $\mathrm{C} 282 \mathrm{Y} /$ C282Y genotype is substantially higher than that of all other genotypes containing HFE mutations. These findings are consistent with studies of HFE protein function, which indicate a greater functional impairment with the $\mathrm{C} 282 \mathrm{Y}$ mutation than with the $\mathrm{H} 63 \mathrm{D}$ mutation. ${ }^{30-32}$

$\mathrm{C} 282 \mathrm{Y}$ heterozygosity may be associated with increased risk, but heterogeneity in the OR estimates for this genotype across studies suggests the risk is influenced by additional factors. The

Table 2

Pooled epidemiologic analysis of 14 studies assessing the contribution of different HFE genotypes to the etiology of hereditary hemochromatosis

\begin{tabular}{lcccc}
\hline Genotype & $\begin{array}{c}\text { Pooled } \\
\text { odds ratio }\end{array}$ & $\begin{array}{c}\text { 95\% confidence } \\
\text { interval }\end{array}$ & $\begin{array}{c}\text { P-value from } \\
\text { test for } \\
\text { heterogeneity }\end{array}$ & $\begin{array}{c}\text { Pooled } \\
\text { attributable } \\
\text { fraction }\end{array}$ \\
\hline C282Y/C282Y & 4383 & $1374->10,000$ & 0.87 & 0.73 \\
C282Y/H63D & 32 & $18.5-55.4$ & 0.26 & 0.06 \\
H63D/H63D & 5.7 & $3.2-10.1$ & 0.17 & 0.02 \\
C282Y/+ & 4.1 & $2.9-5.8$ & 0.01 & 0.03 \\
H63D/+ & 1.9 & $1.5-2.5$ & 0.21 & 0.03 \\
\hline
\end{tabular}




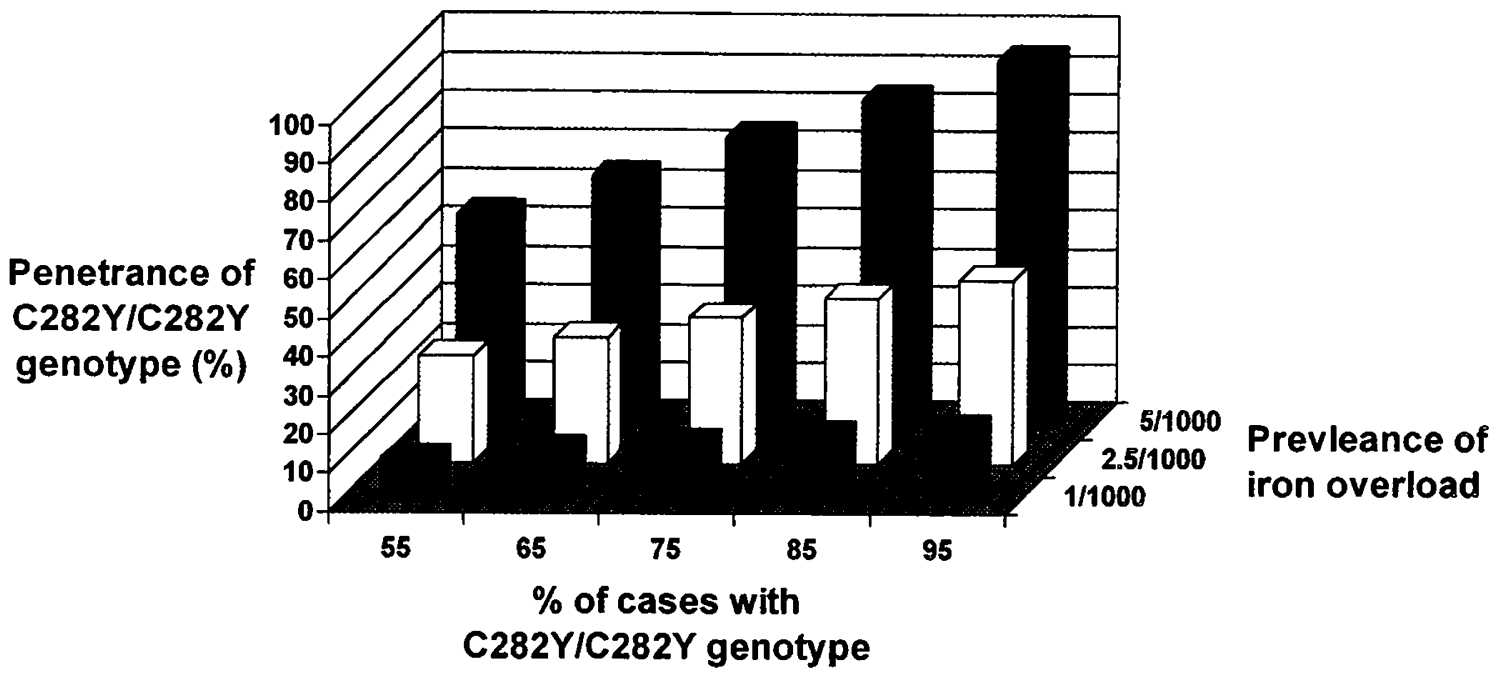

Fig. 1 Estimated penetrance of the $\mathrm{C} 282 \mathrm{Y} / \mathrm{C} 282 \mathrm{Y}$ genotype as a function of the prevalence of iron overload disease and the percentage of cases with the genotype.

Table 3

C282Y/C282Y penetrance: effect of differences in prevalence of genotype ${ }^{a t}$

\begin{tabular}{lcc}
$\begin{array}{l}\text { Prevalence of iron } \\
\text { overload disease } \\
\text { due to } \\
\text { hemochromatosis }\end{array}$ & $\begin{array}{c}\text { Prevalence of } \\
\text { C282Y/C282Y }\end{array}$ & $\begin{array}{c}\text { Penetrance of } \\
\text { C282Y/C282Y } \\
(\%)\end{array}$ \\
\hline 0.0025 & 0.004 & 47 \\
0.005 & 0.004 & 94 \\
0.0025 & 0.006 & 31 \\
0.005 & 0.006 & 63 \\
\hline
\end{tabular}

${ }^{a}$ Calculations assume $75 \%$ of cases carry $\mathrm{C} 282 \mathrm{Y} / \mathrm{C} 282 \mathrm{Y}$ genotype.

Table 4

Penetrance of the C82Y/H63D and H63D/H63D genotypes"

\begin{tabular}{lcc}
$\begin{array}{l}\text { Prevalence of iron } \\
\text { vverload disease } \\
\text { due to } \\
\text { hemochromatosis }\end{array}$ & $\begin{array}{c}\text { Penetrance of } \\
\mathrm{C} 282 \mathrm{Y} / \mathrm{H} 63 \mathrm{D} \\
(\%)\end{array}$ & $\begin{array}{c}\text { Penetrance of } \\
\mathrm{H} 63 \mathrm{D} / \mathrm{H} 63 \mathrm{D} \\
(\%)\end{array}$ \\
\hline 0.001 & 0.3 & 0.04 \\
0.0025 & 0.7 & 0.1 \\
0.005 & 1.4 & 0.2 \\
\hline
\end{tabular}

${ }^{a}$ Calculations assume that $\mathrm{C} 282 \mathrm{Y} / \mathrm{H} 63 \mathrm{D}$ has a prevalence of $2.2 \%$ and occurs in $6 \%$ of cases and that $\mathrm{H} 63 \mathrm{D} / \mathrm{H} 63 \mathrm{D}$ has a prevalence of $2.7 \%$ and occurs in $1 \%$ of cases.

existence of additional mutations contributing to the development of hemochromatosis would be a plausible explanation for this finding. An additional mutation in the HFE gene, $\mathrm{S} 65 \mathrm{C}$, has been described recently, and may explain some cases of clinical expression in $\mathrm{C} 282 \mathrm{Y}$ heterozygotes. ${ }^{17}$ However, nongenetic factors might also modify the risk conferred by the heterozygous state.

Our estimate of the penetrance of the $\mathrm{C} 282 \mathrm{Y} / \mathrm{C} 282 \mathrm{Y}$ genotype varied with assumptions concerning the prevalence of iron overload disease, the prevalence of the genotype, and the proportion cases due to the genotype. Prevalence of iron overload disease had the greatest effect on penetrance estimates (Fig. 1, Table 3). Penetrance of the $\mathrm{C} 282 \mathrm{Y} / \mathrm{C} 282 \mathrm{Y}$ genotype exceeded $50 \%$ only when the prevalence of iron overload disease was set at 5 per 1000 .

In fact, current data make it difficult to estimate the prevalence of iron overload disease with accuracy. Screening studies suggest that the prevalence of people with biochemical measures of iron overload may be as high as 5 per 1000.23 However, a substantial proportion of such people may be asymptomatic. ${ }^{23,27,28}$ One clinical study estimated that $43 \%$ of men and $28 \%$ of women with iron overload will develop serious complications of hemochromatosis ${ }^{28}$; this study was based on the experience of patients seen in a referral center and may represent an upper estimate of penetrance. ${ }^{33}$ No prospective studies have evaluated the likelihood of disease progression in persons found to have biochemical evidence of iron overload at a young age, but screening studies document persons with biochemical measures of iron overload who are asymptomatic at elderly ages. ${ }^{24,34,35}$ Furthermore, case reports have documented elderly people with the C282Y/C282Y genotype who have no clinical evidence of disease. ${ }^{36,37}$

Similarly, clinical diagnoses of hemochromatosis are much less common than would be expected from estimates of iron overload derived from screening studies..$^{25}$ For example, death statistics and hospital records suggest a hemochromatosis prevalence of 1 to 3 per $10,000,{ }^{38}$ a figure that is 10 -fold lower than estimates derived from screening studies. Missed diagnoses may contribute to this discrepancy but are unlikely to account fully for it. Clinical complications of hemochromatosis thus could fall at the lower end of our sensitivity analysis (i.e., at 1 per 1000), yielding a penetrance range for the $\mathrm{C} 282 \mathrm{Y}$ / C282Y genotype of $10 \%$ to $20 \%$.

The penetrance of the $\mathrm{C} 282 \mathrm{Y} / \mathrm{H} 63 \mathrm{D}$ and $\mathrm{H} 63 \mathrm{D} / \mathrm{H} 63 \mathrm{D}$ genotypes is much lower than the penetrance of the $\mathrm{C} 282 \mathrm{Y} /$ $\mathrm{C} 282 \mathrm{Y}$ genotype. Yet persons carrying these genotypes are still 
at substantially increased risk for iron overload disease, compared with persons with a normal HFE genotype. Thus, from a clinical perspective, our study indicates that there is no simple way to define a "positive" or "negative" genetic test for hemochromatosis based on HFE genotype. Even an imperfect genetic test may have clinical utility, but any use of HFE genotype tests for screening or diagnosis must take into account their uncertain predictive value for iron overload disease and, in particular, the limited sensitivity of tests using only the $\mathrm{C} 282 \mathrm{Y}$ mutation.

These findings should be interpreted cautiously because of possible biases in the studies used for the pooled analysis. Sources of bias include the lack of uniformity of case definitions (e.g., studies used different diagnostic criteria, included incident and prevalent cases, and were likely to have included case subjects at different stages of the natural history of hemochromatosis), the possible inappropriateness of the control populations, and the lack of consideration of relevant modifiers such as gender, iron intake, and alcohol use. It is unlikely, however, that these biases can account for the large ORs obtained in the pooled analysis.

Another potential limitation in our results derives from reports of a polymorphism in the HFE gene that may cause an error in PCR analysis, resulting in the misclassification of $\mathrm{C} 282 \mathrm{Y}$ heterozygotes as homozygotes. ${ }^{39,40}$ If this error occurred in the studies included in the pooled analysis, it would cause our analysis to underestimate the penetrance of the $\mathrm{C} 282 \mathrm{Y} / \mathrm{C} 282 \mathrm{Y}$ genotype. However, investigation by the European Haemochromatosis Consortium and a proficiency testing program sponsored by the American College of Medical Genetics and the College of American Pathologists indicate that genotyping errors due to this polymorphism are likely to be rare. ${ }^{41,42}$

Well-designed population-based epidemiologic studies are needed to better characterize the impact of the different HFE genotypes on the absolute and relative risk of clinical complications due to iron overload and to define modifying factors that may contribute to the clinical expression of iron overload due to hemochromatosis. These research efforts will be aided by a consistent case definition for hemochromatosis and systematic measurement of known or potential modifiers of clinical expression such as gender, alcohol use, and hepatitis exposure. ${ }^{1,2}$ Knowledge about genotype-phenotype relationships in hemochromatosis will be improved by such efforts, but our data indicate that the HFE genotype will remain an imperfect predictor of clinical disease.

\section{Acknowledgments}

This work was supported in part by Interagency Personnel Agreement 99IPA6430 between the Centers for Disease Control and Prevention and the University of Washington.

\section{References}

1. Bothwell TH, Charlton RW, Motulsky AG. Hemochromatosis. In: Scriver CR, Beau$\operatorname{det}$ AL, Sly WS, Valle D, editors. The metabolic and molecular bases of inherited disease, 7 th ed. New York: McGraw Hill, 1995.
2. Bacon BR. Diagnosis and management of hemochromatosis. Gastroenterology 1997; 113:995-999.

3. Feder IN, Gnirke A, Thomas W, Tsuchihashi Z, Ruddy DA, Basava A, Dormishian F, Domingo R Jr, Ellis MC, Fullan A, Hinton LM, Jones NL, Kimmel BE, Kronmal GS, Lauer P, Lee VK, Loeb DB, Mapa FA, McClelland E, Meyer NC, Mintier GA, Moeller N, Moore T, Morikang E, Prass CE, Quintana L, Starnes SM, Schatzman RC, Brunke KJ, Drayna DT, Risch NJ, Bacon BR, Wolff RK. A novel MHC class I-like gene is mutated in patients with hereditary hemochromatosis. Nat Genet 1996;13:399-408. mutated in patients with hereditary hemochromatosis. Nat Genet 1996,13:399-408.

4. Mercier B, Mura C, Ferec C. Putting a hold on "Hams PC. Hemochromatosis: clinical implications of genetic testing. Can Med Assoc J 1998;159:156-158.

6. Edwards CQ, Griffen LM, Ajioka RS, Kushner JP. Screening for hemochromatosis: phenotype versus genotype. Semin Hematol 1998;35:72-76.

7. Barton JC, Shih WWH, Sawada-Hirai R, Acton RT, Harmm L, Rivers C, Rothenberg $\mathrm{BE}$. Genetic and clinical description of hemochromatosis probands and heterozygotes: evidence that multiple genes linked to the major histocompatibility complex are responsible for hemochromatosis. Blood Cells Mol Dis 1997;23:135-145.

8. Beutler E, Gelbart T, West C, Lee P, Adams M, Blackstone R, Pockros P, Kosty M, Venditti CP, Phatak PD, Seese NK, Chorney KA, Ten Elshof AE, Gerhard GS, Chorney M. Mutation analysis in hereditary hemochromatosis. Blood Cells Mol Dis 1996; 22:187-194.

9. Borot N, Roth M-P, Malfroy L, Demangel C, Vinel JP, Pascal JP, Coppin H. Mutations in the MHC class 1-like candidate gene for hemochromatosis in French patients. Immunogenetics 1997;45:320-324.

10. Burt MJ, George PM, Upton JD, Collett JA, Frampton CM, Chapman TM, Walmsley TA, Chapman BA. The significance of haemochromatosis gene mutations in the general population: implications for screening. Gut 1998;43:830-836

11. Cardoso EMP, Stal P, Hagen K, Cabeda JM, Esin S, De Sousa M, Hultcrantz R. HFE mutations in patients with hereditary hemochromatosis in Sweden. J Intern Med 1998;243:203-208.

12. Distante S, Berg JP, Lande K, Haug E, Bell H. High prevalence of the hemochromatosis-associated Cys282Tyr HFE gene mutation in a healthy Norwegian population in the city of Oslo and its phenotypic expression. Scand J Gastroenterol 1999;34:529534.

13. Gottschalk R, Seidl C, Loffler T, Seifried E, Hoelzer D, Kaltwasser. HFE codon $63 / 282$ (H63D/C282Y) dimorphism in German patients with genetic hemochromatosis. Tissue Antigens 1998;61:270-275.

14. Jazwinska EC, Cullen LM, Busfield F, Pyper WR, Webb SI, Powell LW, Morris CP, Walsh TP. Hemochromatosis and HLA-H. Nat Genet 1996;14:249-251.

15. McDonnell SM, Hover A, Gloe D, Ou C-Y, Cogswell ME, Grummar-Stawn L. Population-based screening for hemochromatosis using phenotypic and DNA testing among employees of health maintenance organizations in Springfield, Missouri. Am J Med 1999;107:30-37.

16. Moirand R, Jouanolle A-M, Brissot P, Le Gall J-Y, David V, Deugnier Y. Phenotypic expression of HFE mutations: a French study of 1110 unrelated iron-overloaded patients and relatives. Gastroenterology 1999;116:372-377.

17. Mura $\mathrm{C}$, Raguenes $\mathrm{O}$, Ferec $\mathrm{C}$. HFE mutation analysis in 711 hemochromatosis probands: evidence for $\mathrm{S} 65 \mathrm{C}$ implication in mild form of hemochromatosis. Blood 1999;93:2502-2506.

18. Murphy S, Curran MD, McDougall N, Callendar ME, O'Brien CJ, Middleton D High incidence of the Cys $282 \mathrm{Tyr}$ mutation in the HFE gene in the Irish population: implications for haemochromatosis. Tissue Antigens 1998;52:484-488.

19. Piperno A, Sampietro M, Pietrangelo A, Arosio C, Lupica L, Montosi G, Vergani A Fraquelli M, Girelli D, Pasquero P, Roetto A, Gasparini P, Fargion S, Conte D, Camaschella C. Heterogeneity of hemochromatosis in Italy. Gastroenterology 1998; 114:996-1002.

20. Sanchez M, Bruguera M, Bosch J, Rodes J, Ballesta F, Oliva R. Prevalence of the Cys282Tyr and His63Asp HFE gene mutations in Spanish patients with hereditary hemochromatosis and in controls. J Hepatol 1998;29:725-728.

21. UK Haemochromatosis Consortium. A simple genetic test identifies 90 percent of UK patients with haemochromatosis. Gut 1997;41:841-844.

22. Rothman KJ. Modern epidemiology. Boston: Little, Brown and Company, 1986

23. Bradley LA, Haddow JE, Palomaki GE. Population screening for haemochromatosis: a unifying analysis of published intervention trials. J Med Screen 1996;3:178-184.

24. Baer DM, Simons JCL, Staples RL, Rumore DJ, Morton CI. Hemochromatosis screening in asymptomatic ambulatory men 30 years of age and older. Am J Med 1995;98:464-468.

25. Cogswell ME, McDonnell SM, Khoury MJ, Franks AL, Burke W, Brittenham G. Iron overload, public health and genetics: evaluating the evidence for hemochromatosis screening. Ann Intern Med 1998;129:971-979.

26. Phatak PD, Sham RL, Raubertas RF, Dunnigan K, O'Leary MT, Braggins C, Cappucio JD. Prevalence of hereditary hemochromatosis in a sample of 16,031 primary care patients. Ann Intern Med 1998;129:954-961.

27. Olynyk IK, Cullen DI, Aquila S, Rossi E, Summerville L, Powell LW. A population- 
based study of the clinical expression of the hemochromatosis gene. N Engl J Med 1999;341:718-724.

28. Adams PC, Gregor IC, Kertesz AE, Valberg LS. Screening blood donors for hereditary hemochromatosis: decision analysis model based on a thirty-year database. Gastroenterology 1995;109:177-188.

29. Bradley L, Johnson D, Palomaki G, Haddow J, Robertson N, Ferrie R. Hereditary haemochromatosis mutation frequencies in the general population. J Med Screen 1998:5:34-36.

30. Feder JN, Tsuchihashi Z, Irrinki A, Lee VK, Mapa FA, Morikang E, Prass CE, Starnes SM, Wolff RK, Parkkila S, Sly WS, Schatzman RC. The hemochromatosis founder mutation in HLA-H disrupts beta-2-microglobulin interactions and cell surface expression. J Biol Chem 1997;272:14025-14028.

31. Feder IN, Penny DM, Irrinki A, Lee VK, Lebron JA, Watson N, Tsuchihashi Z, Sigal E, Bjorkman PJ, Schatzman RC. The hemochromatosis gene product complexes with the transferrin receptor and lowers its affinity for ligand binding. Proc Natl Acad Sci USA 1998;95:1472-1477.

32. Waheed A, Parkkila S, Zhou XY, Tomatsu S, Tsuchihashi Z, Feder IN, Schatzman RC, Britton RS, Bacon BR, Sly WS. Hereditary hemochromatosis: effects of C282Y and $\mathrm{H} 63 \mathrm{D}$ mutations on association with beta-2-microglobulin, intracellular processing, and cell surface expression of the HFE protein in COS-7 cells. Proc Natl Acad Sci USA 1997;94:12384-12389.

33. Adams PC. Population screening for hemochromatosis. Gut 2000;46:301-303.

34. Balan V, Baldus W, Fairbanks V, Michels V, Burritt M, Klee G. Screening for hemo- chromatosis: a cost-effectiveness study based on 12,258 patients. Gastroenterology 1994; 107:453-459.

35. Elliott R. Lin BPC, Dent OF, Tact A, Smith CI. Prevalence of hemochromatosis in a random sample of asymptomatic men. Aust N Z J Med 1986;16:491-495.

36. Adams PC, Campion ML, Gandon G, LeGall JY, David V, Jouanolle AM. Clinical and family studies in genetics hemochromatosis: microsatellite and HFE studies in five atypical families. Hepatology 1997;26:991-995.

37. Bacon BR, Sadiq SA. Hereditary hemochromatosis: presentation and diagnosis in the 1990s. Am J Gastroenterol 1997;92:784-789.

38. Yang Q, McDonnell SM, Khoury MJ, Cono I, Parrish RG. Hemochromatosis-associated mortality in the United States from 1979 to 1992: an analysis of multiplecause mortality data. Ann Intern Med 1998;129:946-953.

39. Jeffrey G, Chakrabarti S, Hegele R, Adams PC. Polymorphism in intron 4 of HFE may cause overestimation of $\mathrm{C} 282 \mathrm{Y}$ homozygote prevalence in haemochromatosis. Nat Genet 1999;22:325-326.

40. Somerville MJ, Sprysak KA, Hicks M, Elyas BG, Vicen-Wyhony L. An HFE intronic variant promotes misdiagnosis of hereditary hemochromatosis. Am J Hum Genet 1999;65:924-926

41. European Haemochromatosis Consortium. Polymorphism in intron 4 of HFE does not compromise haemochromatosis mutation results. Nat Genet 1999:23:271.

42. Noll WW, Belloni DR, Stenzel TT, Grody WW. Polymorphism in intron 4 of HFE does not compromise haemochromatosis mutation results. Nat Genet 1999;23:271272. 